Gut, 1962, 3, 187

\title{
Measurement of gastrointestinal transit using radioactive chromium
}

\author{
J. HANSKY AND A. M. CONNELL ${ }^{1}$ \\ From the Department of Gastroenterology, Central Middlesex Hospital, London
}

Measurements of gastrointestinal transit until recently have used physical and chemical agents such as barium, bismuth, glass beads (Alvarez and Freedlander, 1924), or carmine (Mulinos, 1935).

Recently Whitby and Lang (1960) showed that chromic oxide $\left(\mathrm{Cr}_{2} \mathrm{O}_{3}\right)$ mixes well with the gut contents, is relatively inert, and is not absorbed from the gastrointestinal tract. Using chemical methods for its estimation, they employed it as a marker in metabolic balance studies. It has also been shown that $\mathrm{Cr}^{51}$ tagged to red blood cells and given orally is not absorbed from the gut, $97 \%$ of the dose being excreted in the faeces (Cameron, 1960).

We decided, therefore, to investigate the use of sodium chromate $\left(\mathrm{Na}_{2} \mathrm{Cr} \mathrm{O}_{4}\right)$ labelled with $\mathrm{Cr}^{51}$ as an index of gastrointestinal transit as it promised to be simple to use and at the same time give a quantitative measure of several parameters of transit including the passage of the main bulk of the marker. Chromic oxide incorporating $\mathrm{Cr}^{51}$ has also become available, and this material has also been studied. In this communication the method of estimating gastrointestinal transit using $\mathbf{C r}^{\mathbf{5 1}}$ is described and its value discussed.

${ }^{1}$ Member of the M.R.C. Gastrointestinal Research Unit.

\section{METHOD}

$\mathrm{Cr}^{51}$ is administered orally either as chromic oxide powder or sodium chromate solution, and all the stools passed during the next five to seven days are individually collected, dried in an oven at $170^{\circ} \mathrm{F}$. for 24 hours, ashed and counted, using the method described by Cameron (1960).

A gelatin capsule, filled with $0.5 \mathrm{~g}$. of chromic oxide, with an activity of 1 to $2 \mu \mathrm{c}$, is swallowed by the subject with a little water. Alternatively, sodium chromate is administered as a solution containing 1 to $2 \mu \mathrm{c}$ of radioactivity made up to a volume of $3 \mathrm{ml}$. with tap water, this being the optimum volume for counting on our apparatus. The solution may be given in tomato juice, orange squash, or by itself, but the tube containing the chromate should be washed at least four times with water and the washings swallowed by the subject. Even after washing, the tube should be counted for residual radioactivity as we have found up to $5 \%$ of the dose left in the tube.

The use of a well type scintillation counter (ECKO) permits accurate results with only a small dose of $\mathrm{Cr}^{51}$ and in this study the dose was always less than $2 \mu \mathrm{c}$.

In order to assess the value of the method, the excretion of a dose of $\mathrm{Cr}^{51}$ has been estimated in 10 normal subjects, six receiving chromic oxide and four sodium chromate solution.

TABLE I

PERCENTAGE RECOVERY OF RADIOACTIVE CHROMIC OXIDE AND SODIUM CHROMATE AND TRANSIT TIMES IN 10 NORMAL SUBJECTS

\begin{tabular}{|c|c|c|c|c|c|}
\hline Subject & Material Used & $\begin{array}{l}\text { Time to Initial } \\
\text { Appearance (hr.) }\end{array}$ & $\begin{array}{l}\text { Time to Maximal } \\
\text { Appearance }(\mathrm{hr} .)\end{array}$ & $\begin{array}{l}\text { Time to Final } \\
\text { Appearance (hr.) }\end{array}$ & $\%$ Recovery \\
\hline $\begin{array}{r}1 \\
2 \\
3 \\
4 \\
5 \\
6 \\
7 \\
8 \\
9 \\
10\end{array}$ & 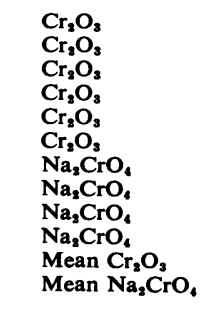 & $\begin{array}{l}10 \\
17 \\
19 \\
22 \\
32 \\
41 \\
24 \\
24 \\
26 \\
28\end{array}$ & $\begin{array}{r}35 \\
41 \\
34 \\
35 \\
49 \\
41 \\
67 \\
73 \\
117 \\
46\end{array}$ & $\begin{array}{r}68 \\
95 \\
89 \\
72 \\
91 \\
96 \\
91 \\
165 \\
145 \\
95\end{array}$ & $\begin{array}{r}80 \\
80 \\
80 \\
80 \\
73 \\
88 \\
100 \\
85 \\
89 \\
80 \\
80 \cdot 2 \\
88 \cdot 5\end{array}$ \\
\hline
\end{tabular}




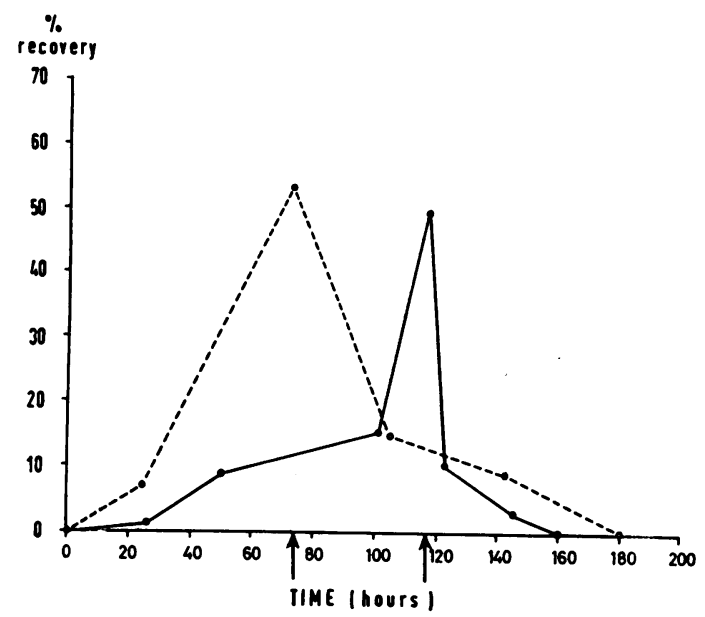

FIG. 1. Excretion of $\mathrm{Cr}^{51}$ by two subjects. The points represent the percentage of the total dose excreted in each stool specimen passed after administration of $\mathrm{Cr}^{51}$. The arrows indicate the maximum percentage excretion in the two subjects.

\section{RESULTS}

Table I presents the results of the study. The mean percentage recovery of radioactivity in the 10 experiments was $83.5 \%$ and the range $73 \%$ to $100 \%$. The mean recovery of chromic oxide was $80.2 \%$ and that of sodium chromate $88.5 \%$.

There was a wide variation in the time taken for the marker to appear, the time taken for it to disappear, and the time taken for the maximum quantity of radioactivity to be excreted. Eight of the 10 subjects excreted the total recoverable dose within 96 hours. For the 10 subjects, the mean percentage of marker excreted in 24 hours was $22.4 \%$, in 48 hours $54.3 \%$, and within 96 hours $76.1 \%$. While the time of appearance and disappearance of the marker may be very similar on two different occasions, the time to reach the maximum quantity may vary widely. Figure 1 illustrates this and presents the excretion of $\mathrm{Cr}^{51}$ in two different subjects. In one subject the time to reach the peak was 73 hours and in the other 117 hours. There was therefore an important difference in the handling of the marker which would not have been demonstrated using older methods of study.

\section{COMMENT}

This method permits quantitative measurement of several parameters of gastrointestinal transit. It has the advantage of being physiological, and as far as is known, neither chromic oxide nor sodium chromate have any action on the alimentary tract (Whitby and Lang, 1960; Roche, Perez-Gimenez, Layrisse, and Di Prisco, 1957). More important, it permits the measurement of the rate of passage of the maximum bulk of the marker which cannot be done using current methods such as barium or carmine which give information only about the rate of passage of the head and tail of the column.

Alvarez and Freedlander (1924) gave coloured glass beads to the subjects to estimate transit and showed that normal subjects passed $15 \%$ in 24 hours, $50 \%$ in 48 hours, and $75 \%$ in 96 hours. In so far as a comparison can be made, our results agree with those of Alvarez.

Another important use of an unabsorbable marker is in absorption studies, and recently Wiggins and Dawson (1961) have used polyethylene glycol and phenol red as a marker in studies of fat absorption. Radioactive chromium is advanced as a simple and quantitative alternative to the chemical substances at present available as markers in gastro-intestinal study.

We wish to express our thanks to Dr. T. D. Kellock for his helpful criticism and to Miss P. B. Wilcox and Mis. E. E. Cox for technical assistance.

We wish to thank Mr. W. E. Godding and Mr. Sassoon of the Westminster Laboratories for their interest and for the supply of irradiated chromic oxide.

\section{REFERENCES}

Alvarez, W. C., and Freedlander, B. L. (1924). The rate of progress of food residues through the bowel. J. Amer. med. Ass., 83, 576-580.

Cameron, A. D. (1960). Gastro-intestinal blood loss measured by radioactive chromium. Gut, 1, 177-182.

Mulinos, M. G. (1935). The value of selective drugs in the treatment of constipation. Rev. Gastroent., 2, 292-301.

Roche, M., Perez-Gimenez, M. E., Layrisse, M., and Di Prisco, E. (1957). Study of urinary and fecal excretion of radioactive chromium $\mathrm{Cr}^{51}$ in man. Its use in the measurement of intestinal blood loss associated with hookworm infection. J. clin. Invest., 36, 1183-1192.

Whitby, L. G., and Lang, D. (1960). Experience with the chromic oxide method of fecal marking in metabolic balance investigations on humans. Ibid., 39, 854-863.

Wiggins, H. S., and Dawson, A. M. (1961). An evaluation of unabsorbable markers in the study of fat absorption. Gut, 2, 373-376. 